\section{Et brev fra diplomaten Stephen Lesieur til Christian IV's lutenist John Dowland}

\author{
„Mr. Dowland... satisffiie me very \\ particularly of what yow shall think \\ worthie my knoledge for her ma. ${ }^{\text {sties }}$ \\ seruice... your very louing frend Steph: \\ Lesieur"
}

\section{Af redaktor og projektforsker Peter Hauge}

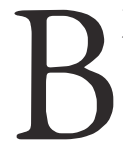
landt Det Kongelige Biblioteks mere kuriøse samlinger af breve findes en, som har tilhørt Christian IV's sekretær Jonas Charisius (Ill. 1). 'Ved første gennemsyn af de omkring 200 breve, som er skrevet på latin, fransk, spansk, italiensk og engelsk, får man indtrykket af en noget uens samling omhandlende emner lige fra jura og historie over takkeskrivelser til politik. En stor del af brevene kan generelt karakteriseres som 'videregivelse af informationer'. En del af de danske - det vil sige skrevet på latin af danske diplomater - og en del af de engelske beskriver en bestemt, længerevarende politisk episode, der måske endda kan betegnes som en af de mere alvorlige kriser mellem Danmark og England lige før og efter 1600-tallet. Generelt skyldtes krisen strid om fiskerirettigheder ud for Norge og Island, men Christian IV's opkrævning af Øresundstolden forbedrede heller ikke situationen.

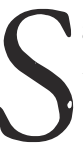
amlingen indledes med en håndskrevet registrant over brevskrivere og datoer (Ill. 2). Registranten, som formodentlig stammer fra det syttende eller attende århundrede, optegner tilsyneladende langt flere breve, end samlingen på Det Kongelige Bibliotek har, hvilket kunne tyde på, at en del er endt et andet sted. Blandt de mere interessante, som desværre ikke er tilstede i Charisiuses samling, er en „Apologie“ af Sir Walter Rawleighe (eller Raleigh), den berømte engelske opdagelsesrejsende, pirat og skribent. ${ }^{2}$ Et andet måske lige så interessant navn er J. P. Sweelinck fra Amsterdam, som kunne være den berømte hollandske organist og komponist Jan Pieterszoon Sweelinck. ${ }^{3}$ Hvis man nærlæser navnet, står der faktisk „Sweelnick “ og ikke Sweelinck. Enten er den anonyme skriver af registranten kommet til at bytte rundt på ' $n$ ' og 'i', eller også er der virkelig tale om en helt anden person. ${ }^{4}$ En del af brevene er slet ikke adresseret til Charisius, og nogle er endda dateret lang tid før, han blev sekretær. ${ }^{5}$

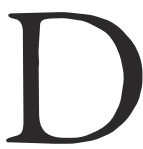
er findes også en lille korrespondance på fransk og spansk mellem en Antonio Suarido de Arguillo og le Prince et Marquis de Baden om militære emner." På omslaget til brevene er med fremmed hånd tilføjet datoen 16. marts 1599 og ordene: „les conceptes de deux lettres trouvees parmÿ les bagages de Marquis de Baden" - altså at koncepterne til to breve blev fundet blandt Marquis de Badens bagage. Denne mystiske bemærkning kan tyde på, at Marquis de Badens bagage på en eller anden måde var blevet endevendt, og brevene konfiskeret, for senere at ende hos Charisius. Et andet brev, som findes i samlingen, dateret Helsingør den 7. december 1598, er fra en William Leighton, som med stor sandsynlighed er den samme som amatørdigteren og -komponisten Sir William Leighton ${ }^{7}$ og ven af tidens største og mest berømte lutenist John Dowland (1563-1626). 


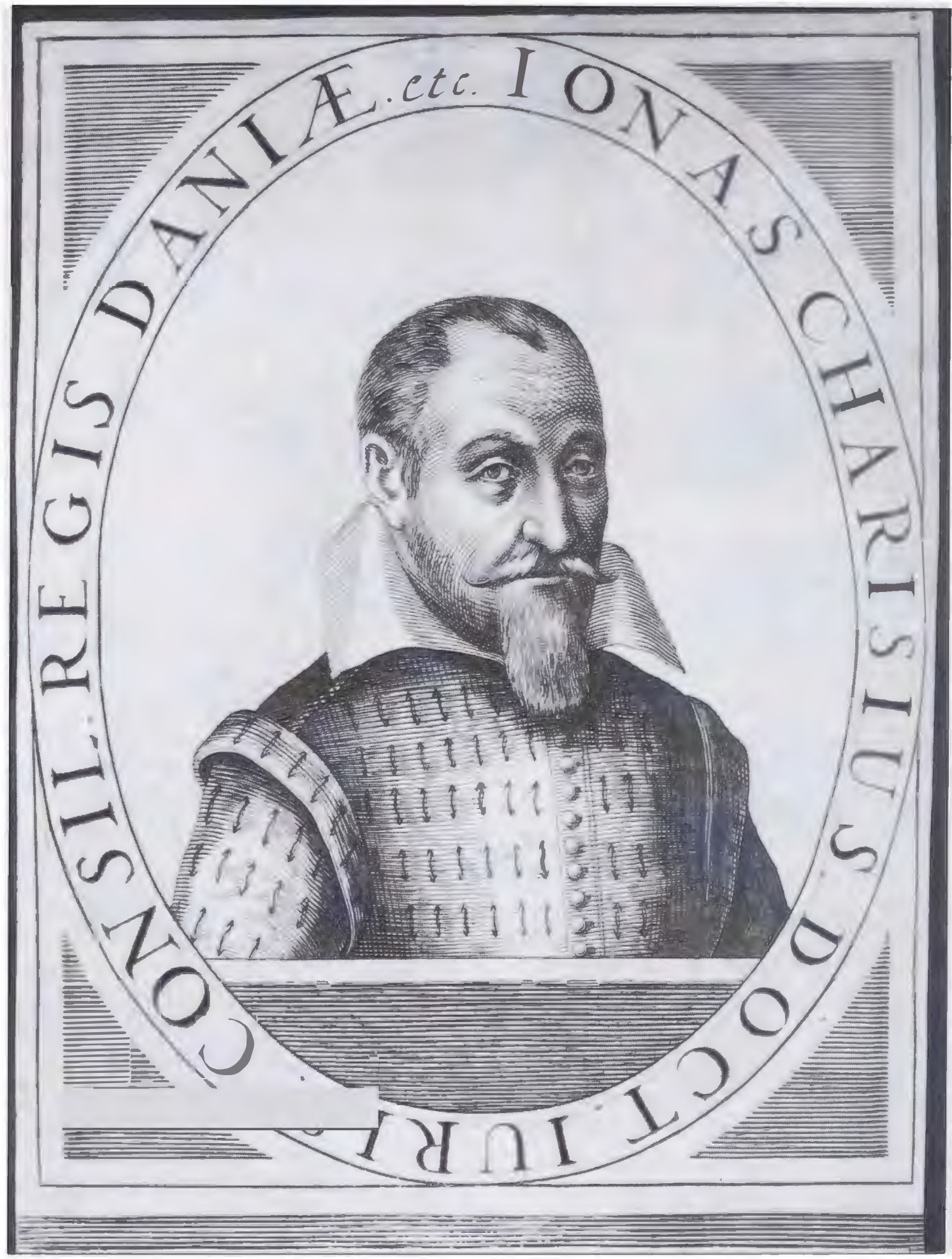

Ill. 1: Portrat afJonas Charisius. Kobberstik afH. Hondius.

(Det Kongelige Bibliotek, Billedsamlingen). 
Således kommer vi - fra en musikhistorisk synsvinkel - nok til den mest interessante del af samlingen: et brev adresseret til Dowland, der i perioden 15981606 var ansat som kongelig lutenist hos Christian IV. I dag kender man således kun til to breve fra Dowlands korrespondance: et, som han skrev til Elizabeth I's 'Secretary of State' Robert Cecil i $1595 ;{ }^{8}$ mens det andet er det nærværende brev i Det Kongelige Bibliotek, adresseret til lutenisten i 1602. At der er overleveret så få personlige breve fra den gang er måske ikke i sig selv usædvanligt; personlige breve er oftest kun relevante for brevskriver og adressat, og brevene ville derfor højst sandsynligt være blevet destrueret kort tid efter, at de var blevet læst. Men dette personlige brev til Dowland er gemt i et arkiv, som har tilhørt Jonas Charisius, og må derfor på en eller anden måde have spillet en vigtig rolle for det danske statsapparat. Spørgsmålet er, hvad er det i brevet, der var så vigtigt, at det blev arkiveret hos Christian IV's sekretær?

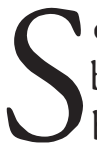
om nævnt beskæftiger mange af brevene sig med en bestemt politisk begivenhed. Allerede fra før århundredeskiftet havde der været en lang række problemer mellem Danmark og England, blandt andet vedrørende handel og sejlads på Rusland nord om Norge og fiskerirettigheder ud for det nordlige Norge og Islands kyster." Nogle af problemerne var forsøgt løst af Frederik II og Elizabeth I i 1583, da begge lande underskrev en traktat; alligevel fortsatte stridighederne med uformindsket styrke. Fra engelsk side klagede man over den dårlige behandling, engelske fiskere fik i Island og nægtede at acceptere dansk højhedsret over Nordhavet. Fra dansk side gik klagen til gengæld på, at englænderne opbragte danske og norske handelskibe i Nordsøen; i England var man nemlig nervøse for, at handelskibene leverede varer til den spanske fjende.

I 1597 blev en dansk delegation sendt til England for at rette en klage til dronning Elizabeth I, men intet hjalp. Aret efter sendte Christian IV Dr. Krag til London ligeledes for at klage - igen uden noget resultat. I 1598 sendtes en engelsk delegation til Danmark, men heller ikke de formåede at komme nogen vegne. Det rygtedes samtidig i England, at den danske konge havde opfordret James VI af Skotland ${ }^{10}$ til at indlede en krig mod England. ${ }^{11}$ Situationen optrappedes, og under Christian IV's berømte sejlads til Nordkap i 1599 opbragtes flere engelske skibe, hvilket skabte furore i England, der endnu en gang sendte en delegation til Danmark for at klage. Året efter blev man dog enige om at forhandle om en løsning på problemerne et neutralt sted, og Emden i Tyskland blev valgt. Desværre ankom den engelske delegation omtrent en måned for sent, hvorfor den danske delegation først blev utålmodig $\mathrm{og}$ dernæst fornærmet. Da englænderne endelig ankom, rejste de danske hjem, idet de sagde, at de ikke havde mere tid. ${ }^{12}$

Situationen blev yderligere tilspidset af, at det i England i begyndelsen af 1602 rygtedes, at Christian IV ville støtte Elizabeths modstandere og blandt andet sende en lastfuld kanoner til Spanien. ${ }^{13}$ Det fik den danske konge til at foreslå en ny dato og sted til forhandling - denne gang i Bremen - og den engelske dronning accepterede tilbudet. ${ }^{14}$ De nye forhandlinger begyndte i slutningen af september. Trods mange diskussioner frem og tilbage kom parterne ingen vegne. Efter to måneder forlod de danske udsendinge mødet, idet de sagde, at de måtte konsultere kongen. 


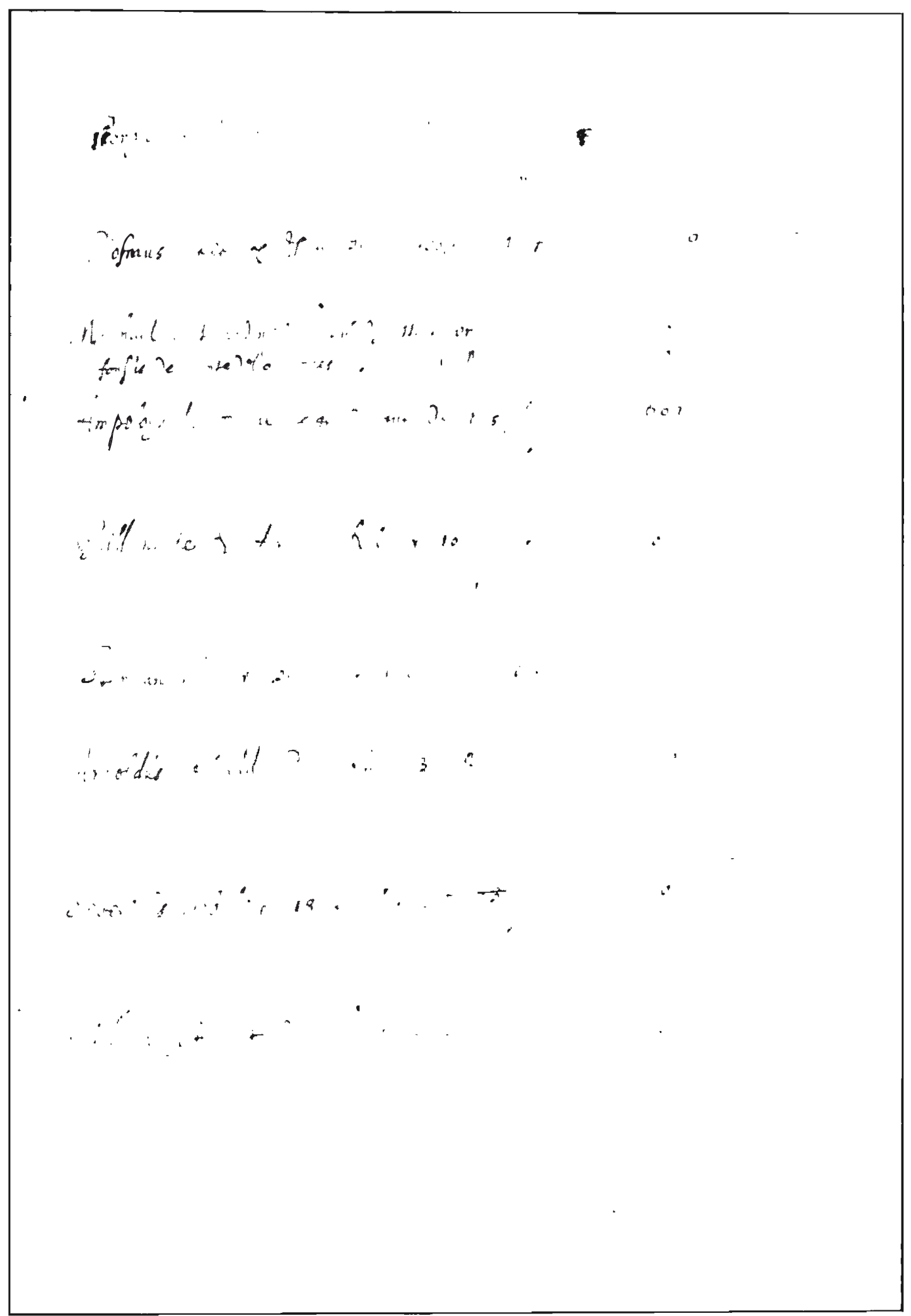

Ill. 2: Registrant over breve i Jonas Charisiuses samling. (Det Kongelige Bibliotek, Håndskriftafdelingen). 
Englænderne måtte således forblive i Bremen og afvente et dansk udspil. Der var stor fare for, at der skulle opstå alvorlige forviklinger i forhandlingerne.

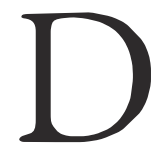
et var i denne anledning, at den engelske diplomat Stephen Lesieur ${ }^{15}$ den 9. december 1602 skrev et længere brev med en lille, næsten ulæselig håndskrift til Dowland. Efter en længere indledning, hvori han hurtigt gennemgår forløbet i Bremen, kommer han frem til brevets centrale formål: „I shalbe very glad from tyme to tyme to heere from yow of as muche as may concerne her ma.stie or her subiects, <that $>$ shall come to $<$ your> knoledge [...] spare not any reasonable charge to do it for I will see yow repaid“. Lesieur ønsker således, at Dowland skaffer oplysninger, som er relevante for England; til gengæld vil diplomaten sørge for, at Dowland bliver belønnet på en eller anden måde. Det fremgår tydeligt af brevet, at man fra engelsk side er en smule desperat og har brug for informationer om, hvad den danske konge tænker, og om eventuel dato og sted for hvornår, der vil finde en diskussion sted, sandsynligvis i Rigsrådet. Lesieur slutter af med at skrive, at han vil gøre Elizabeth opmærksom på Dowlands „true hart and seruice“ - altså hans troskab over for England og indsats i denne vigtige sag.

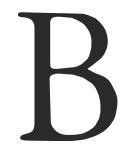
revet er ganske tankevækkende, for det viser flere ting om Dowland. For det første må Lesieur have vidst, at Dowland var modtagelig for en sådan henvendelse, eller i det mindste at der var en chance for, at lutenisten ville påtage sig et så risikabelt hverv for det engelske statsapparat - meget tyder også på, at de to har kendt hinanden. For det andet kunne Lesieur tilbyde noget til gengæld, som han nøje må have vidst, at Dowland ville være interesseret $\mathrm{i}$ - altså for eksempel at blive belønnet med en stilling ved Elizabeths hof. Sidst, men ikke mindst, så har Lesieur også vidst, at Dowland må have været meget tæt på den danske konge for overhovedet at kunne skaffe de ønskede oplysninger. At Lesieur valgte Dowland og ikke en af de mange andre englændere, der færdedes ved hoffet og i det hele taget i København (og Helsingør), skyldtes formodentlig ikke bare, at de højst sandsynligt var venner, men også den kendsgerning, at netop den kongelige lutenist var en af de ganske få, som havde adgang til majestæten stort set hver dag. Han var endda formodentlig med på kongens forskellige rejser rundt i riget. Lutten er et lydsvagt instrument og blev snarere anvendt ved intime lejligheder end ved store gallaforestillinger med mange larmende mennesker. Han har nok også kunnet overvære samtaler, mens han spillede og bevægede sig i de private gemakker. Det kan selvfølgelig også tænkes, at kongen og Dowland har talt sammen.

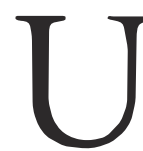
$\mathrm{d}$ fra de engelske kilder, det vil sige memoranda, skriftlige taler og breve, er der meget, der tyder på, at forhandlingerne mellem de to lande var politisk højt prioriteret. ${ }^{16}$ Englænderne var ikke overraskende interesseret $i$, at man fandt en for dem fordelagtig løsning, og hvad der også antydes i brevet til Dowland, så havde man svært ved overhovedet at finde ud af, hvad danskerne egentlig ønskede sig og forventede af de problematiske forhandlinger.

\section{Omkring fire måneder efter at} Lesieurs brev var afsendt, døde den aldrende Elizabeth I i marts 1603, og hele sagen fik en ny drejning. ${ }^{17}$ Dowlands chancer for at få 


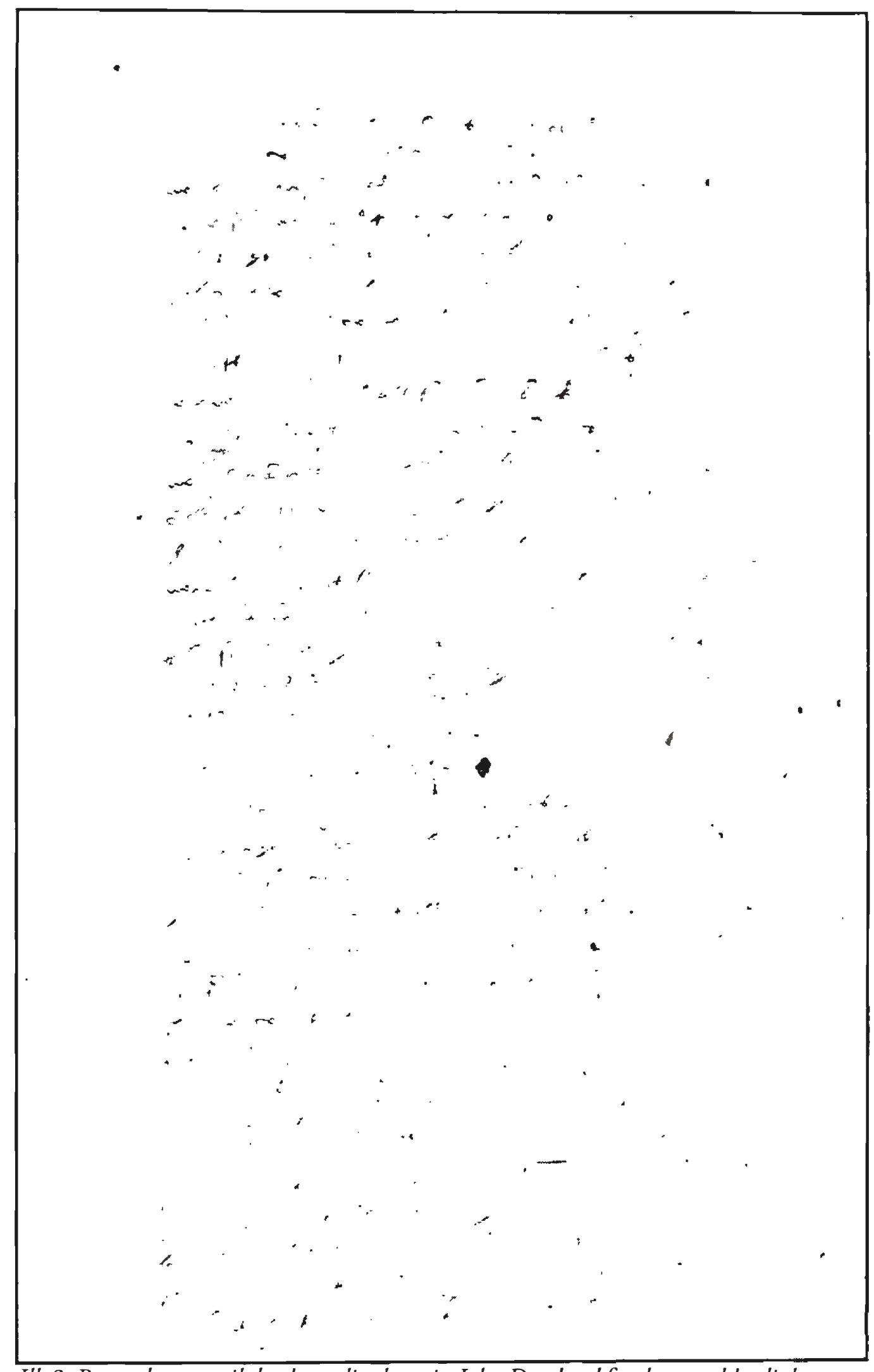

Ill. 3: Brev adresseret til den kongelige lutenist John Dowland fra den engelske diplomat 


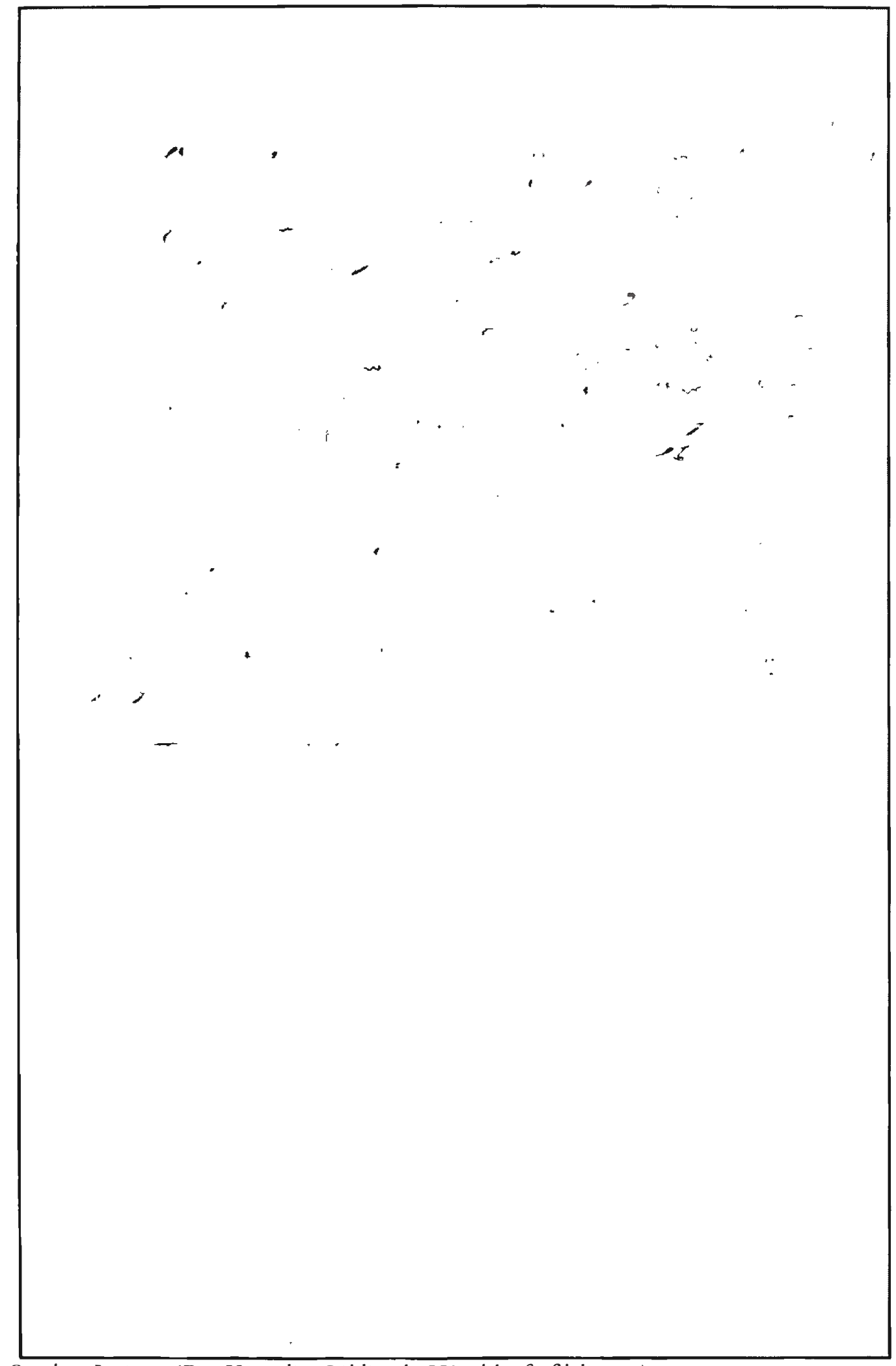

Stephen Lesieur. (Det Kongelige Bibliotek, Håndskriftafdelingen). 
en stilling hos Elizabeth var nu forpasset, og Lesieur ville ikke kunne opfylde det, han havde lovet Christian IV's lutenist. I øvrigt beklagede Lesieur dronningens død, idet han pointerede, at det havde indskrænket hans muligheder for at avancere. ${ }^{18}$ Den nye regent James I af England, Skotland, Irland og Frankrig var gift med Anne af Danmark, søster til Christian IV. Forholdet mellem Danmark og England blev hurtigt forbedret, selv om man ikke umiddelbart fandt en løsning, og allerede i juni 1603 blev Christian IV tildelt den berømte engelske hosebondsorden. ${ }^{1 \text { "Hvis Dowland havde }}$ skaffet de ønskede oplysninger, og var han blevet opdaget, kunne han nu ikke forvente at blive beskyttet af det nye engelske regentpar og selvfølgelig slet ikke af Christian IV. Samtidig ville Dowland have meget svært ved at fa en stilling ved det engelske hof, med mindre han fik fuld accept af Christian IV til at vende tilbage. Det fik Dowland ikke.2(1)

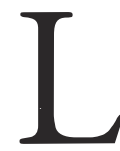

esieurs brev til Dowland er ikke et klart bevis på, at lutenisten faktisk havde held med at skaffe informationer; brevet opfordrer kun Dowland til at gøre det. Der er endog indicier for, at han slet ikke har modtaget brevet, idet det fremgår, at Lesieur er lidt utålmodig og ikke forstår, hvorfor han i meget lang tid ikke har hørt fra sine danske kilder, heriblandt Dowland. Man kunne forestille sig, at dette interessante brev - $\mathrm{i}$ lighed med brevene mellem Marquis de Baden og Antonio Suarido - på en eller anden måde var blevet opsnappet og afleveret til Jonas Charisius og dermed anbragt i arkivet. Dette ville måske nok have fået følger for Dowland. En anden mulighed er, at så snart Dowland havde modtaget opfordringen til at skaffe informationer, afleverede han brevet til Christian
IV's sekretær. Men dermed havde han samtidig afskåret sig fra nogensinde at få sit livs største ønske opfyldt: at blive ansat ved det engelske hof. Man kan også forestille sig, at Dowland havde gemt brevet, og at det først blev fundet i 1606, da han forlod landet - iøvrigt samme år som Christian IV besøgte England. ${ }^{21}$

U $\mathrm{d}$ fra de mange modstridende oplysninger, der er om Dowland, må man nok konkludere, at han var en noget kompliceret personlighed, måske endog en selvhøjtidelig og skuffet person. Tilsyneladende var han utilfreds med, at han havde meget svært ved at få en stilling hos Elizabeth og derfor måtte rejse rundt i Europa. Allerede som sytten-årig blev Dowland ansat hos den engelske ambassadør Henry Cobham²- i Paris, hvor han omgikkes katolikker og endte med at konvertere. Efter nogle år vendte han tilbage til England, hvor han søgte en ledig stilling ved hoffet, men fik den ikke - ifølge ham selv, fordi han nu var katolik. Han var derefter en kort tid hos blandt andre Mouritz, Landgreve af Hessen, hvorefter han rejste til Italien og mødte engelske katolikker, som forberedte sig på at snigmyrde den engelske dronning. I 1595 forsøgte Dowland - måske nok lidt desperat og måske med frygt for hvad der kunne ske ham, når han vendte tilbage til England - i et langt brev til Elizabeths sekretær Robert Cecil at forklare sin omgang med de farlige elementer og fortalte ligeledes om sammensværgelsen..$^{23}$ Af brevet fremgår det også, at Dowland var overbevist om, at årsagen til, at han ikke fik en stilling ved Elizabeths hof, netop var hans tidligere katolske sympatier. Hans egen forklaring er dog ikke helt holdbar, idet der var en del katolske musikere ansat ved hoffet; som eksempler kan 
nævnes William Byrd og Thomas Morley. ${ }^{24}$ Umiddelbart kan det virke lidt underligt, at Dowland nærmest uopfordret skrev et langt brev til Cecil; men netop omkring dette tidspunkt overtog Cecil officielt stillingen fra den berømte og berygtede Francis

Walsingham, der havde ledet en effektiv organisation af agenter og spioner både i England og i resten af Europa. ${ }^{25}$ Det var ikke usædvanligt, at Walsingham anvendte musikere som agenter. Således afsløredes for eksempel hoforganisten, musikforlæggeren og komponisten Thomas Morley som spion, og den italienske musiker og komponist

Alfonoso Ferrabosco I blev beskyldt for at være det, selv om det ikke er entydig bevist. ${ }^{2 n}$ I sammenligning med Dowlands mulige spionage er Morley og Ferrabosco dog små fisk uden adgang til de helt store politiske sager.

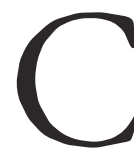

ecil, som var særdeles interesseret $\mathrm{i}$ alle de oplysninger, han kunne få vedrørende krig og ikke mindst handel, valgte dog ikke at bruge Walsinghams net af agenter; i stedet for oprettede han sit eget system af informatorer. I et memorandum fra 1598 forklarer Cecil, at han ligefrem havde agenter $\mathrm{i}$,Scotland, Holland and Zeeland, Italy, Germany, Denmark and Sweden".2- Det kan meget vel tænkes, at Dowland blev en del af dette, især da han gennem sit brev til Cecil havde vist sin villighed til at aflevere følsomme informationer. På trods af at Dowland i februar 1598 blev opfordret til at vende tilbage til Hessen af Landgreve Mouritz, valgte han dog Danmark, hvortil han ankom senest i efteråret samme år. ${ }^{28}$ Det kan meget vel tænkes, at han ankom sammen med en af de engelske delegationer, som på det tidspunkt blev sendt til Danmark, blandt andet for at protestere over at engelske skibe var blevet opbragt. Dowland var måske allerede på det tidspunkt blevet udset af Cecil som en mulig informant, såfremt situationen krævede det. I 1606 vendte Dowland tilbage til sin kone og børn i England efter at have været væk i otte år. Først i 1612 blev han ansat ved hoffet som lutenist, men som hans ven Henry Peacham skriver i sin emblembog (Dowland er her nattergalen Philomel):

Heere Philomel, in silence sits alone, / In depth of winter, on the bared brier, / Whereas the Rose, ${ }^{2 "}$ had once her beautie showen; / Which Lordes, and Ladies, did so much desire: / But fruitles now, in winters frost, and snow, / It doth dispis'd, and unregarded grow.

So since (old frend,) thy yeares have made thee white, / And thou for others, hast consum'd thy spring, / How few regard thee, whome thou didst delight, / And farre, and neere, came once to heare thee sing: / Ingratefull times; and worthles age of ours, / That let's us pine, when it hath cropt our flowers. ${ }^{30}$

Lesieurs brev til Dowland indeholder talrige oplysninger og leder til nye overvejelser omkring Dowland som person og komponist. Alt dette vil der blive redegjort for i en kommende artikel, som også vil indeholde en transkription af brevet. ${ }^{31}$ 
Noter:

1 Jonas Charisius (1571-1619) studerede både ved Universitetet i Padua og i Heidelberg, før han i 1598 blev ansat som sekretær i Christian IV's tyske Kancelli. Samlingen har signaturen NKS 1305, 2".

2 Sir Walter Raleigh (ca. 1554-1618) blev adlet i 1585, men i 1603 blev han anklaget for højforræderi og først løsladt tretten år senere, dog uden at man frafaldt sigtelserne; han blev henrettet i 1618 . „Apologie“, som oprindelig var i Charisiuses samling, kan have været en afskrift af den berømte forsvarstale, som Raleigh skrev kort før henrettelsen.

3 J. P. Sweelinck (1562-1621); ifølge registret var brevet dateret Amsterdam, den 10. april 1617.

4 At registranten nævner et brev af „William Leigthon" [sic!], som viser sig at være Leighton, sandsynliggør, at "Sweelnick“ kan være en fejl.

5 Det tidligste brev i samlingen er dateret 1571, mens det seneste er fra 1618.

6 Brevene er henholdsvis dateret 3. januar 1599 og 8. marts 1598 (calculus florentinus; det vil sige 1599).

7 Sir William Leighton (ca. 1565-1622), udgav i 1612 The Teares or Lamentations of a Sorrowfull Soule, til hvilken Dowland bidrog med et digt og to kompositioner. Det har ikke tidligere være kendt, at Leighton var i Danmark i 1598.

8 Sir Robert Cecil (1563-1612), first Earl of Salisbury, adlet i 1603 som Baron Cecil of Essendon og i 1604 som Viscount Cranborne.

9 Om forholdet mellem Danmark og England på dette tidspunkt se Edward P. Cheyney, 'England and Denmark in the Later Days of Queen Elizabeth', Journal of Modern History 1 (1929), s. 9-39.

10 James (1566-1625), søn af Mary Queen of Scots, blev allerede i 1567 kronet som kong James VI af Skotland.

11 Årsagen, til at Christian IV havde opfordret
James til at begynde en krig mod Elizabeth, skulle angiveligt have været på grund af mistanke om, at hun overvejede at vælge Lord Essex som sin efterfølger, jf. British Library, MS Add. 4125, 'Anthony Bacon Papers', fol. 308.

12 Regesta Diplomatica historia danica (København 1895), series II.1 (1537-1607), s. 811-2.

13 Edward P. Cheyney, 'England and Denmark in the Later Days of Queen Elizabeth', The Journal of Modern History 1 (1929), s. 34.

14 Se for eksempel Regesta Diplomatica historice danica (København 1895), series II.1

(1537-1607), s. 824-5.

15 Stephen Lesieur (virksom 1582-1626),

"Gentleman of her Majesty's bedchamber" og diplomat, sandsynligvis oprindelig franskmand; i 1598 ansat hos Robert Cecil, for hvem han var hovedagent for Hansestæderne i Nordtyskland.

16 British Library, MS Add. 48128 og 48152.

17 Allerede den 3. april 1603 meddelte den nye engelske konge James I Christian IV, at „han imod al Forventning enstemmig er kaaret til Konge i England", jf. Regesta diplomatica (København 1895), series II.1 (1537-1607), s. 830.

18 Jf. Dictionary of National Biography, udg. Sidney Lee (London 1893), bd. 23, s. 67.

19 Jf. W. A. Shaw, The Knights of England (London 1906, genoptrykt 1971), bd. 1, s. 29: The Order of the Garter, „1603, June 14 Christiern IV, king of Denmark. Installed by proxy 1605 , sept. $8^{\prime \prime}$. Hvor meget, man skal lægge i dette, kan diskuteres: James var berømt (og berygtet) for at uddele ordener ved enhver given lejlighed; dette fremgår tydeligt af listerne i Shaws The Knights of England.

20 Til gengæld fik Dowland tilladelse fra kongen til at rejse til England „Vdj hans eigenn Werffue" i sommeren 1603 og først et år senere er han tilbage i Danmark, jf. Rigsarkivet, 'Rentemesterregnskab', 16045, fol. 590v. 
21 Dowland blev afskediget i februar1606, og Christian IV rejste til England i sommeren 1606.

22 Sir Henry Cobham (1538-1605?).

23 Brevet, som er det mest udtømmende, man har om Dowland, befinder sig i Hatfield House, gengivet i Diana Poulton, John Dou'land (London 1982, 2. udg.), planche 1, transkriberet s. 37-40.

24 William Byrd (1543-1623), Gentleman of the Royal Chapel; Thomas Morley (15571602), ligeledes Gentleman of the Royal Chapel.

25 Sir Francis Walsingham (1532-1590), Elizabeths førstesekretær 1573-1590 er især kendt for at opklare katolske konspirationer mod Elizabeth, for eksempel afsløringen af Francis Throckmortons sammensværgelse 1583, som involverede både Frankrig og Spanien, og Anthony Babingtons i 1586.

26 Alfonso Ferrabosco I (1543-1588), i England 1562 og i 1576 udnævnt til Gentleman of the Privy Chamber, men måtte forlade landet i 1578.

27 Alan Haynes, Invisible Power: The Elizabethan Secret Services, 1570-1603 (Stroud 1992), s. 140.

28 Dowland fik løn fra den 18 . november 1598 , jf. transkription af Rentemesterregnskaberne i Det Kongelige Bibliotek, 'Hagens Samling' 1.4.

29 Rosen skal her sandsynligvis forstås som 'The Tudor Rose', det vil sige Elizabeth I.

30 Henry Peacham, Minverva Britanna, or a Garden of Heroical Devises (London s.d.), s. 74.

31 Peter Hauge, 'Political Disputes between England and Denmark 1598-1606: Was Dowland an Informant at the Danish Court?' The Lute 41 (2001). 